\title{
Agriculture and growth nexus in Gambia
}

\author{
Bukhari Sillaha \\ a Department of Economics, College of Business Administration, King Saud University.
}

H I G H L I G H T S:

1. The paper focuses on agriculture and economic growth nexus in Gambia.

2. The paper utilizes extensive historical context to the agriculture policies adapted so far in Gambia.

3. The window of the study is 1966 to 2009 .

4. A vector error correction technique to examine the growth-agriculture relation in the Gambia is applied.

5. Interestingly, the capital per worker is found to be a significant and relevant factor input for the economic growth, while agricultural labor per acre is irrelevant in both the short run and the long run analyses.

\section{Article History}

Received: 06-10-2013

Accepted: 19-11-2013

Available online: 30-11-2013

\section{Keywords:}

Agriculture output;

Economic growth;

Ghambia;

VECM.

\begin{abstract}
A B S T R A C T
Agriculture is a major engine for the economic well-being of the Gambia. The successive governments from the colonial periods to the present have all recognized this importance of the agricultural sector but failed to do something that bear any fruit since government encouraged slash and burn technology and putting increasingly more people onto the land instead of increasing the yields per acre. More people than before do remain still on the land, but they are now poorer than their forefathers. Using autoregressive and vector error correction techniques to examine the growth-agriculture relation in the Gambia for the period from 1966 to 2009, it is found that the capital per worker is a significant and relevant factor input for the economic growth. The agricultural labor per acre is found to be irrelevant in both the short run and the long run analyses. The agricultural productivity measured as crop yields per acre is the most important variable for the economic growth in the Gambia. It boosts both the economic growth and the capital formation in the country. The agricultural policies should be focused on increasing the crop yields per acre not having more people back to the land. The processing, services and small manufacturing sectors should be developed and built into the agricultural policies in order to create redeployments for the agricultural labor surpluses.
\end{abstract}

DOI: http://dx.doi.org/10.18533/jefs.v1i01.33

F47; F48; 011; 041

(C) 2013 The Authors. This is an open access article under the terms of the Creative Commons Attribution License 4.0, which allows use, distribution and reproduction in any medium, provided the original work is properly cited.

\subsection{Introduction}

The Governments of the Gambia, in the colonial era, in the first Republic and in the Second Republic, have all endeavored relentlessly to improve the livings of the poor agricultural farmers of the Gambia, who constitute more than $70 \%$ of the population. The situation for more than a century now is far from desirable. Poverty still ravages more than $60 \%$ of the agricultural farmers. In each instance, an intervention was introduced - and the intervention was often an initial government investment, or a donor-driven investment or both - the situation improved and promised better living for the agricultural farmers; and when the intervention was removed, by demanding the project to be self-sustaining, the situation deteriorated and became worse than pre-intervention era, causing havoc in the social fabrics and economic foundations of the agricultural farmers. The result is massive rural urban migrations and increasing number of illegal migration of able-bodied young men to Europe and other parts of the world. The few agricultural farmers left behind do subsistence farming to complement the remittances to sustain 
women, children and elderly. Those who have surplus remittances would erect structures and engage in distributive trade. If no further intervention is mounted, the agricultural industry will not take off, and assume that the remittances are not sustained increasingly - which could be done by increasing the number of new and affluent migrants to replace the old migrants, who have become emptied out of able-bodiness or got assimilated into new found lands - many of the farming communities will become ghost villages, the country may become one city reeling with unemployment and poverty. This chapter believes that agricultural industry in the Gambia is just like that of Japan and Europe is sacrosanct and untouchable, therefore it should be supported as long as the people of the Gambia continue to eat and drink. This chapter is organized as section 2 discusses the background; section 3 reviews some relevant literature, section 4 discusses the methods of estimation, section 5 analyzes the findings, and section 6 derives the conclusions and policy recommendations. The chapter employs Error Correction Method to examine both long run and short run relations between the agricultural variables and per capita GDP; it employs the vector error correction technique to estimates the long run co-integrating vectors. It examines the Granger causality effects between the agricultural variables and the per capita GDP. Agriculture has been held to be the mainstay of the Gambian economy, unfortunately no scientific research has been undertaken in order to formulate evidence based policies. This chapter expects to contribute significantly to filling in this gap in the agricultural intervention projects, which are widely awash in the country.

\section{$2.0 \quad$ Backgrounds}

In this section, we discuss some relevant efforts and interventions introduced by different governments in order to try to improve the living of the farming communities. We achieve this by examining agriculture in the preindependence, the First Republic and the Second Republic.

\subsection{Agriculture in the pre-independence}

Trading in agricultural produce with international world was introduced by the British in $1820^{1}$ in response to the high demand in North America and Europe for the groundnut oil, which was used for cooking oil, industrial oil, lubricants and production of soap and candles. The nut itself was introduced by the Portuguese in the sixteenth century. The farmers responded to the policy in order to obtain the colonial money to pay taxes and purchase the imports. By 1904, the welfare of the country was solely dependent on this groundnut, a situation that raised a concern of the government as they state in the 1904 Report, "It is a difficult matter in a small colony like the Gambia to deal year after year with question of agriculture. The groundnut is the main product, and the export has so often been described that there is nothing fresh to add beyond once again stating that the welfare of the colony depends entirely on this crop. The people devote almost their whole attention to it, only growing small quantities of rice, millet, Koos, and corn for food".

The agricultural technology was simply slash and burn, and land was not of a constraint, but labor. The population of the country was just $196101^{2}$ in 1911 . Labor shortage was addressed by boosting population growth through the strange farmers, who would come from neighboring countries to produce groundnut in the Gambia during the rainy season. Their number reached 32, 220 in 19153, and they contributed annually on average one third of the groundnut export. The national population rapidly increased to 210530 in 1921 indicating an increase of 44\% from that of 1911. The school expansion was restricted in the rural regions to further increase labor on the land. The agriculture industry was formalized with the establishment of Department of Agriculture in 1924. Its main function was to demonstrate species of plants for suitability to the Gambia. The groundnut trade flourished inducing further population growth as the farmers multiplied themselves, and the more strange farmers preferred to stay to avoid the frequent to and fro trips to their homelands. To improve land fertility, farmers practiced two techniques, one is fallow system, whereby the land would be left uncultivated for 15 to 30 years, and the other was to interchange crops in the same land. These techniques were dependent on the availability of abundant arable lands. But as the population kept rising, the fallow duration diminished, and lands were annually cultivated with increasing number of labor. This allowed the diminishing returns to quickly set in; the groundnut yields dwindled and hence the farm incomes which also used to finance the food purchases, the farmers were not producing adequate food cereals because the groundnut sales were then sufficient to purchase food. The government response was to subsidize food imports particularly and mechanize the agriculture that was carried out $100 \%$ with human labor. They brought animal-powered moldboard ploughs, Emcot ridges and ox carts in 1940. The food insecurity continued to haunt farmers and the government, and food import subsidy became a costly burden on the government budget. This forced the government to try import substitution of rice, which became a staple diet for the average Gambian. The Colonial development Corporation enclosed an area of 9600 hectares for the rice irrigation project, which involved canalization of leveled fields to be fed by the tidal flow of the river Gambia. Mechanical traction was introduced to rice production. Due to poor canalization system, less than $10 \%$ of the hectares planted survived the flooding. The project also converted rice farmers into low wage laborers, a situation which led many to shun it. It later changed to sharecropping, which landed the farmers into accumulated debts as the groundnut yields and prices fell, and farmers turned the rice project into subsistence farming; thus, the input credits could not be repaid. As the land 
productivity further diminishes, the food security worsens with increasing population, which was then growing at a rate of 19.3\%, on average, per annum from 1921 to $1963^{4}$, and consequently the demand for credit to purchase farm inputs, such as seeds, fertilizer and implements kept increasing. Also, the funds were not easily available to purchase the groundnut, in some instances produce were bought on credit, further complicating agricultural life for the farmers. Two years before the colonial government handed the reign to the self-rule, they state "Reports of experts received during the period have suggested that one of the main factors retarding the agricultural economy, in spite of the efforts of the Government's agricultural services with its long experience of farming in Gambia conditions, has been shortage of credit. Hopes of filling this gap lie largely in the co-operative movements; and these movements lead to the formation of Gambia Central Co-operative Banking and Marketing Union"5. Finances did not get better as agriculture continued to be dependent on government direct support, and the new independent Gambia was born on $18^{\text {th }}$ February 1965 inheriting a fledging agricultural sector.

\subsection{Agriculture in the first republic}

The First Republic is the government that led the country to independence from the British and continued to reign until 1994 when it was overthrown through a military takeover. The British were in hurry to leave the Gambia as it did not represent any economic interest, but rather an economic draining. The Gambia Central Co-operative Banking and Marketing Union (later transformed into Gambia Produce Marketing Board) became a self-sustaining entity, purchasing the produce on cash and giving credits to the farmers to improve the production. By 1970, the first republic embarked on economic plans, calling for increased self-sufficiency, stabilized producer prices and expanded government agricultural extension services. A newly independent country yearning for other nonindependent countries to be independent, the Gambia found Taiwan a sister in the struggle, and hence diplomatic relations were established. The latter responded to the call of the Gambia by sending technical missions to try the rice mechanization. In 1966, Taiwan developed 1200 hectares of rice irrigation scheme water fed by diesel powered pumps. Fertilizers, seeds and fuel were provided free to farmers in the first year tasking the farmers to be selfsustaining in the following years. The scheme faced technical difficulties, and was later taken over by personnel from the Mainland China in 1974 as the Gambia changed the diplomatic ties. The Chinese continued the work of the Taiwanese missions, and by 1980 less than half of the project area started by Taiwan was cultivated. The project resulted in high credit burdens on farmers, who had to shoulder the financings burdens of the project during dwindling groundnut yields and the 1970 -1977 Sahelian droughts. The government cry for international help was heeded of by the World Bank, which in an attempt to combat food insecurity consolidated the Taiwanese irrigation scheme of 1200 hectares, but maintained farm credit, further worsening the credit status of the farmers. The situation could not be sustained, as farmers started abandoning the projects that would impound their produce sales for loan repayments. The rice project was abandoned and groundnut sales fell. The government had then no choice but to cancel and forgive all loan repayments in 1979 and 1980. But food insecurity did not go away, in fact, worsened by the droughts; and the government finances were strained. Again food import substitution of rice was an option. The government supported by donors embarked on heavy mechanized rice irrigation called JahallyPacharr smallholder Rice Project in 1983 , with a development cost of $\$ 46500^{6}$ per hectare. It could only survive effectively for five years. Again similar reasons for the failures were repeated, loan repayment difficulties (subsistence farmers were asked to pay capitalist loan repayments, which translated into asking a non-market to pay a market price), technical failures and fuel shortages. From the drought episodes of 1970 to 1977 and the failed ambitious rice projects combined with price controls to temper the food insecurity and stabilize the groundnut producer prices and subsidize farm inputs, the government continued to accumulate toxic assets on its budgets, which were found unsustainable. In 1985, it embarked on cleaning up its own finances, which was termed economic recovery program. It removed subsidies, floated the prices and curtailed the public expenditures particularly in the areas of agricultural extension services. It removed taxes on groundnut exports, and encouraged private sector participation in the agriculture. It failed to understand that private sector seldom invests in industries characterized by diminishing returns and undifferentiated products. The lands have become too marginal due to traditional land tenure structures, where the lands were continuously split up to accommodate additional members as the population kept rising. The farmers were then farming on increasingly smaller and smaller plots of lands, which after some time had to be cultivated all year round. Thus, production increase demanded increasingly more farm improvements, which became costly to the farmers. Food insecurity continued to haunt the farmers, and hence more resources than before were allocated to food imports rather than capital accumulation, a phenomenon that in the long run would further impoverish the country.

In 1993, the government commissioned one Michael Roemer from the Agency for International Development to examine industrialization strategies that could bail out the country from its long protracted poverty and place it on a path of sustainable development and growth. He examined three industrialization options for the Gambia, and tried to look for a model country in the South East Asia or elsewhere. The options were resource based industrialization, which would involve exporting what the country has from land, water and tourism, then moving slowly to the second option of manufacturing goods that would substitute for the re-exported goods, and working towards positioning the Gambia as all open economy and haven for the investors or a managed openness. He 
concluded by stating that "the keys to rapid income growth and reduction in poverty are rapid and sustained growth of exports, especially of manufactures, and of productivity, together with high saving and investment ration". That is, agriculture cannot be, and has never been, a long term sustained source of income growth and poverty reduction. The first Republic did not have much time to digest Michael's proposal as it was toppled the following year in a military takeover.

\subsection{Agriculture in the second republic}

The second Republic expanded and revitalized the frontiers of agriculture that were earlier opened by the previous regimes. The frontiers were geared towards battling the long term enemies of the country, food insecurity and poverty. The solution, as can be deduced from the practice of the regime lies in "Back to Land", and "Operation Feed the Nation" through intensive mechanization to increase the production of cereals, rice and groundnut. In 1996, it imported 20 four wheel tractors, and before 2001 more than $70^{7}$ tractors were imported and given to the farmers, and currently there are more than 500 tractors in the country for the agriculture. ${ }^{8}$

Relations were re-established with Taiwan, which quickly dispatched its technical missions to the Gambia to revitalize the rice irrigation works, which used to be performed by the Taiwanese more than 21 years ago. Fertilizers, farm inputs and more tractors were imported and offered for sale to the subsistence farmers. The "Back to Land" clarion was somewhat responded to by the people as the cultivated land increased from 0.273 hectares per person in 1994 to 0.323 hectares per person in 2001, an increase of $18.39 \%$ in arable land cultivation. The yields increased from $1122 \mathrm{~kg} / \mathrm{ha}$ in 1994 to $1230 \mathrm{~kg} / \mathrm{ha}$ in 2001 . The mechanization of agriculture still did not go far, as some farmers are of the view that tractors are not properly designed for the soil, which is too light, and tractors often over pulverize it resulting in erosion and loss of valuable topsoil. Kuye al et (2006) find that as of 2002 only $1.7 \%$ of farm work was carried out by mechanical power; the majority of farm work, $73.4 \%$ was done with animals. Food security did not get better as food prices kept rising, the price of the stable diet, rice, has more than tripled in the span of 1994 to 2001, while the farm income measured by the groundnut price has kept crawling and sometimes declining. The country continues to import on average 66,000 tons $^{9}$ of rice annually. The 2003 Census has found that more than $50 \%$ of the Gambians live on less than a dollar a day. The National Nutrition Agency has revealed that more than $50 \%$ of people in the affluent administrative regions, the Capital City Banjul and the Kanifing Municipality are suffering from mild to severe food insecurity ${ }^{10}$. The Government is weighing options again to increase rice production; a new design of farmer managed rice irrigation is underway to minimize pump irrigation schemes, which have often placed unbearable technical and other running costs on the farmers.

To conclude this background review, we state that agriculture as a source of food security and foreign exchange still remains a distant dream for the Gambia after more than 100 years of struggle. The pre-independence failed to practice land enclosures that spurred agricultural industrialization in Europe; lands in the Gambia became too marginal with the increasing population as the lands were split up into numerous ownerships. Cash crop, groundnut, became the only hope for the farmers to modernize their living standards, because that was offering a small opportunity to participate in an exchange economy. Upland cereals were produced for subsistence, and rationally no one wanted to remain in the subsistence economy. Farmers have to then choose an optimal combination between exchange economy and subsistence economy, an equilibrium that was never reached due to increasing population, diminishing returns, droughts and socio-economic repercussions of the failing government interventions, such as rice irrigation schemes and agricultural extensions. The result is constant food insecurity, scary poverty and massive rural urban migration and overseas illegal migration. The Greater Banjul Area, which has the best arable lands in the country, is being cut into smaller and smaller pieces of brick-wall fenced dwellings; or grabbed for speculation. The overseas illegal migration is costing more lives year after year; the costs are beyond quantity as the lives lost can be never restored. The situation does not call for more people back to land, which is in odd with the modern agricultural trend that has moved away from labor intensive technology to capital one. In the industrialized countries less than $5 \%$ of population works on the land. But with best technology, they are able to feed themselves, accumulate capital, feed the other $95 \%$ of the population and ship the excess surplus to us in Africa. More people on land imply poverty specialization; they will on average produce the same undifferentiated things to be sold mostly to themselves and non-farmers who constitute a small portion of the population. This results in falling producer prices, and hence falling farm incomes. As farm incomes fall, no asset can be accumulated because the income will barely meet the food expenses. With an endowment of 550,000 arable lands adding more labor will quicken the diminishing returns and clog the country deeper into subsistence economy.

The country requires fewer labors with high technology on the land, where water, fertilizers and pesticide should be abundantly available almost at no cost to farmers. The excess farm labor should be exported to manufacturing and services industries that require minimum sophisticated education. The thrust of this paper is to evaluate the effects of agricultural productivity and agricultural labor on the economic growth and economic well-being of the Gambia. 


\subsection{Literature review}

The importance of agricultural sector to the economic well-being, and especially for developing countries cannot be overemphasized. The developing countries, which are the low income countries, have higher agricultural GDP and higher agricultural employment than the high income countries. This can be seen from the structural composition of GDP in the table below:

\begin{tabular}{lcll}
\hline & Table 01: Change of structural composition of GDP as income rises \\
\hline Sector & Low-income countries & $\begin{array}{l}\text { Middle-income } \\
\text { countries }\end{array}$ & High-income countries \\
\hline Agriculture & $27 \%$ & $10 \%$ & $2 \%$ \\
Industry & $30 \%$ & $36 \%$ & $30 \%$ \\
Services & $43 \%$ & $36 \%$ & $68 \%$ \\
\hline
\end{tabular}

Source: Kidane et. al (2006)

As the income rises, people spend less on food, and agriculture consists mainly of food, the agricultural GDP tends to fall, and thus farm income left unsupported is destined to fall as the income rises. This becomes even fast occurring in the globalized economy where urban rich can further increase their income level by increasingly consuming cheap and subsidized food from the developed countries. The farmers, who often are also the rural people, will get trapped in the income poverty as they cannot move from the land to industries that rarely exist in the urban areas much more in the rural areas. This falling income will further depress rural trade and investment, because trade and investment flourish where purchasing power is. If the economy cannot move people from land to industries, then it should sustain them on the land to avoid and prevent rural urban migration, which leads to unsustainable pressure on the urban amenities and in turn to unsustainable economic prosperity. This principle of sustainable development and prosperity has been well adopted by the industrialized countries and recently industrialized countries. They introduced a complex array of agricultural support policies for price stabilization, input subsidies and direct income payments to prevent the decline of farmers' incomes. In the periods 1986 - 1988, and 1999 2001, the producer support equivalents (PSE) in OECD countries stood at 38 per cent and 33 per cent respectively, Tokarick (2005). The support was weighed heavily towards the price stabilization, which represented 82 per cent and 70 per cent for the period respectively. These were the same periods when World Bank and IMF were commanding African governments to remove agricultural supports and to adhere to textbook market principles. If it is a matter of textbook economics principles, Switzerland should just rely on other European countries with large scale agricultural economies for food, but no, Switzerland in 2001 had PSE of 69 per cent, the highest in the world. To further prevent the decline of farmers' income, which as we mentioned earlier is natural effect of the rising income, the developed countries have resorted to direct income payments to farmers. In EU, farmers received prices that were 33 per cent higher than the world price in 2001, Tokarick (2005). The United States of America has introduced a legislation to subsidize bio-fuel, which among other things, is a policy to directly support farm income; in 2005 farmers received a subsidy of $\$ 0.51$ per gallon of ethanol blended and used as a motor fuel, Rubin et. al (2008). The European Union Council Regulation 1257/1999, in pursuit of sustainable rural development, has allowed the governments to massively fund the processing and marketing of agricultural products, Trefflich et. al (2007). The programme's objectives which are ideal for any developing country are to 1. preserve and provide new jobs in rural areas, 2. give rural people a prospective future and 3. stop and prevent rural urban migration.

The EU has learned that these objectives cannot be achieved without direct government intervention, and thus subsidy has been legislated. It pays to subsidize and support the agricultural sector; the case of the developed countries are clear evidence; the economies prospered with reduced food prices without the same time causing farmers to lose income and get trapped in poverty, because their incomes are supported through a complex sets of agricultural support policies that ultimately end up achieving the aforementioned objectives. This historical fact has missed the textbook economics, which has been dominated by the neo-classical mindset. To bring out some scientific evidence from the historical data, Harley (2002) applies CGE to 1841 British capitalist agriculture, and finds evidence that, despite its inefficient failure to equate marginal product of labor to various uses, has increased labor and peasant welfare. Brivand et. al (2005) find agricultural support to impact favorably on the regional economic growth after controlling for human capital. Subsidy increases the agricultural output and agricultural taxation lowers the per capita income in the economy, Lopez (2002). O' Ryani and Miller (2003) using a CGE analysis for Chile find that an increase in the agriculture increases the real income twice as much as compared to industry in the presence of price subsidy. Bednarikova and Doucha (2009) examine various agricultural support policies on certain regions in Czech Republic and find that all the policies have negative impacts except the direct income payment. Some studies, such as Xu (1993), Longzehn et. al (1996), and Robinson et. al (1997) have looked specifically at the price support policy and they conclude that this particular policy has a negative impact on the economy. These studies do help authorities shape certain policies, but have no evidence to make a strong case for or against the agricultural subsidy. In the current paper, we attempt to examine the agricultural impacts on the welfare of the economy. The study is motivated by the desire to provide some scientific evidence for the case of the Gambia, 
where agriculture has been the backbone of the economy but has recently been marginalized by macroeconomic policy makers. The recent upsurge of interest in the sector by the government should be guided by some scientific evidence from the economy's data, and hence the thrust of this paper.

\subsection{Methods}

Economic theory of production holds that output is a function of capital, labor and technological process. This paper argues that the per capita GDP in the Gambia is a function of capital, labor and agricultural per capita output. The agricultural output captures the economic activity level of $70 \%$ of the population and their purchasing power. Thus, the production function is specified in a log form as:

$$
\ln Y_{t}=\alpha+\beta_{1} \ln K_{t}+\beta_{2} \ln A L_{t}+\beta_{3} \ln A_{t}+\varepsilon_{t}
$$

Where, $\ln Y=\log$ per capita GDP current market prices in USA Dollars, $\operatorname{lnK}=\log$ capital (capital formation) per labor in USA Dollars, $\ln A \mathrm{~L}=\log$ agricultural labor per acre labor force ( number of persons per acre), $\log A=\log$ per capita agricultural output, which is here crop yields in kilograms per acre and $\varepsilon$ is the error term. The data come from the World Bank database of World Development Indicators. There were some missing observations on the labor variables, which were then calculated by the author. More than $70 \%$ of the labor force is in the agriculture; and to bring out the relevance of this force and its use of land to cultivate, the paper introduces the agricultural labor per acre of lands used in crop production for the period of time. This is more meaningful than the gross labor force, and in this way, the model includes in its explanatory variables two agricultural factors, the agricultural output and the agricultural labor. The agricultural labor fluctuates between one person cultivating more than one acre to two persons sharing one acre. From 1960 to 1967, one person cultivated more than one acre; this changed to a one-to-one ratio from 1968 to 1979. The ratio stood at two persons to an acre from 1980 to 1991. The call of "back to land" was significant in the period from 1992 to 1998, as two persons cultivated less than an acre. It then stood at two persons to an acre from 1999 to 2009. The agricultural labor grew at an average rate of 3.3\% per annum during the period from 1960 to 2009; whereas the arable land conversion to the farming land grew at an average rate of $1.3 \%$ in the same period. Given the fact that the arable lands are fixed in amount, the natural law of diminishing returns will inevitably set in if the agricultural labor continues to grow at the rate of $3.3 \%$ per annum. More interestingly, these significant changes in the agricultural labor did not correspond with increased output as the crop yields per acre barely exceeded $1100 \mathrm{~kg}$ per acre for this period. For the estimation purposes, the paper uses the observations from 1966 to 2009 due to unavailability of data on capital formation and GDP before 1966.

\subsection{Autoregressive procedure}

Let equation (1) be a long run relationship between the left side and the right side variables, and that $\mathrm{Y}^{*}$ is the equilibrium level of per capita GDP that the economic agents wish to attain given the capital stock, the labor force and the agricultural output. With this assumption, equation (1) becomes:

$$
\ln Y_{t}^{*}=\alpha+\beta_{1} \ln K_{t}+\beta_{2} \ln A L_{t}+\beta_{3} \ln A_{t}+\varepsilon_{t}
$$

Equilibrium value of $\mathrm{Y}$ is unobservable, but at any given time, the agents adjust their per capita GDP towards its target level, and employing the partial adjustment process, this behavior of the agents can be described as:

$$
\ln \left(Y_{t}-\ln Y_{t-1}\right)=\lambda\left(\ln Y_{t}^{*}-\ln Y_{t-1}\right), \quad 0 \leq \lambda \leq 1
$$

Equation (3) states that the current per capita GDP level moves partially from its previous level towards the desired equilibrium level, and the amount of adjustment is $\lambda\left(\ln C_{t}^{*}-\ln C_{t-1}\right)$ where lambda $\lambda$ indicates the speed of adjustment. By substituting for the value of the equilibrium $Y$ from equation (2) into equation (3) and solving for the observed value of the current $Y$, an autoregressive model appears:

$$
\ln Y_{t}=\lambda \alpha+(1-\lambda) \ln Y_{t-1}+\lambda \beta_{1} \ln K_{t}+\lambda \beta_{2} \ln A L_{t}+\lambda \beta_{3} \ln A_{t}+v_{t}
$$

If there is an adjustment, the short run and long production elasticities can derived by estimating equation (4) as:

$$
\ln Y_{t}=b_{0}+b_{1} \ln Y_{t-1}+b_{2} \ln K_{t}+b_{3} \ln A L_{t}+b_{4} \ln A_{t}+v_{t}
$$

The coefficients of equation (5) are the short run elasticities. The knowledge of these coefficients helps derive the long run elasticities in equation (2).

\subsection{Error correction method (ECM)}


Another way to look at the long relation in equation (1) is to assume a gap between the left side variable and the right side variables and that it is corrected at every particular time to maintain the equilibrium balance between the two sides. This gap is the error term in equation (1):

$$
\ln Y_{t}-\alpha-\beta_{1} \ln K_{t}-\beta_{2} \ln A L_{t}-\beta_{3} \ln A_{t}=\varepsilon_{t}
$$

The adjustment towards the equilibrium depends on the amount of error previously committed, or specifically,

$$
\left(\ln Y_{t}-\ln Y_{t-1}\right)=\delta \varepsilon_{t-1}+e_{t}
$$

$$
\Delta \ln Y_{t}=\delta \varepsilon_{t-1}+e_{t}
$$

The coefficient of the lagged error term in equation (7) is the amount of error corrected at every particular time towards the equilibrium. For this correction to take place it should be significant and negative. Equation (7) is expanded to include not only the lagged error term of the long relation, but also the lagged adjustments of the dependent variable and the contemporaneous and lagged adjustments of the explanatory variables to capture all the potential adjustment processes in the relation towards the equilibrium. These adjustments disappear when the equilibrium is attained. Incorporating these potential adjustments processes in equation (7), results in the error correction procedure as below:

$$
\Delta \ln Y_{t}=b_{0}+\sum_{i^{\prime}=1}^{q} b_{1 i} \Delta \ln Y_{t-i}+\sum_{i=0}^{n} b_{2 i} \Delta \ln K_{t}+\sum_{i=0}^{m} b_{3 i} \Delta \ln A L_{t-i}+\sum_{i=0}^{p} b_{4 i} \ln A_{i}+\delta \varepsilon_{t-1}+v_{t}
$$

When the adjustments processes are complete, the long equilibrium relation of equation (1) emerges from equation (8) as the coefficient of the lagged error term becomes negative one. However, the long run coefficients of equation (1) are not easily derived from equation (8), unlike the case of equation (5). To derive the long coefficients, the value for the lagged error term from equation (6) is to be substituted in equation (8), which will consequently reduce the degrees of freedom. Given the limited observations, the paper stops at equation (8) and analyzes the adjustment processes of the model. Two lags are introduced to adhere to the data limitation constraint.

\subsection{Co-integration test}

If the coefficient of the lagged error term in equation (8) is significant and negative, and the variables in equation in equation (1) are integrated of order one, then a co-integration is established between the left side variable and the right side variables in equation (1). Co-integration is a long co-movement between variables; the variables do not diverge, but co-move within a relation. This relation here can be identified as a production function of per capita GDP that co-moves permanently with capital stock, labor and agricultural output. This relation can be unidirectional or bi-directional depending on whether GDP Granger causes agricultural output, or agricultural output Granger causes GDP, or both Granger cause each other. This feedback process between the variables is tested using the Engle-Granger causality test.

\subsection{Granger causality test}

If agricultural output, A, Granger causes per capita GDP, Y, then the present value of per capita GDP can be predicted by using past values of the agricultural output, and vice versa. This test is performed as

Feedback test from oil consumption and oil price to per capita GDP

$$
Y_{t}=\beta_{0}+\sum_{i=1}^{q} \beta_{1 i} \ln K_{t-i}+\sum_{i=1}^{m} \beta_{2 i} \ln A L_{t-i}+\sum_{i=1}^{n} \beta_{3 i} \ln A_{t}+u_{t}
$$

Feedback test from per capita GDP agricultural output

$$
A_{t}=a_{0}+\sum_{i=1}^{q} a_{1 i} \ln K_{t-i}+\sum_{i=1}^{m} a_{2 i} \ln A L_{t-i}+\sum_{i=1}^{n} a_{3 i} \ln Y_{t-i}+v_{t}
$$

If the sum coefficients of agricultural output in equation (9) are significantly different from zero, then the changes in the per capita GDP can be predicted using the past values of the agricultural output. The feedback will run from per capita GDP to agricultural output, if the sum coefficients of per capita GDP in equation (10) are significantly different from zero. The paper uses 4 lags in the test. This means past two year values are assumed to hold information about the current value of another variable if there are to be feedback processes.

\subsection{Empirical analyses}




\subsection{Autoregressive model}

This model presents the short run and long run relationships between the per capita GDP and the explanatory variables of capital per worker, agricultural labor per acre and the crop yields per acre as shown in table 2 below. The estimates show that no short run relations exist between per capita GDP and the agricultural labor per acre and the crop yields per acre. The capital per worker is found to have both short run and long run relation with the per capita GDP. In the short run and the long run, a unit increase of capital per worker corresponds on average, other things constant, with 0.48 unit increase and 0.99 unit increases respectively with the per capita GDP.

A unit increase of agricultural labor per acre corresponds in the long run with 21 units increase of per capita GDP. The crop yields per acre have a wrong expected sign in this model. This could indicate the poor productivity contribution of the agricultural sector to the economy. This model might not fit the data as well as all the variables in the model are found to first difference stationary, and thus level OLS estimates could be spurious. The contemporaneous relation between the per capita GDP and the explanatory variables is investigated in the error correction model.

\subsection{Error correction method}

In this method the paper examines the contemporaneous relations in the growth-agriculture nexus and searches, if any, for an equilibrium adjustment in the long run relation. Table 3 presents the error correction method estimates.

\begin{tabular}{|c|c|c|c|c|}
\hline \multicolumn{5}{|c|}{ Table 03: Error correction model } \\
\hline Variable & Coefficient & Std. Error & t-Statistic & Prob. \\
\hline $\mathrm{C}$ & 0.005854 & 0.017350 & 0.337407 & 0.7379 \\
\hline $\mathrm{D}(\mathrm{LY}(-1))$ & 0.134681 & 0.187238 & 0.719305 & 0.4770 \\
\hline $\mathrm{D}(\mathrm{LK})$ & 0.326793 & 0.079438 & 4.113832 & 0.0002 \\
\hline $\mathrm{D}(\mathrm{LK}(-1))$ & 0.006676 & 0.091702 & 0.072806 & 0.9424 \\
\hline $\mathrm{D}(\mathrm{LAL})$ & -0.006577 & 0.210426 & -0.031256 & 0.9753 \\
\hline $\mathrm{D}(\operatorname{LAL}(-1))$ & 0.097794 & 0.210152 & 0.465351 & 0.6447 \\
\hline $\mathrm{D}(\mathrm{LA})$ & -0.070097 & 0.134972 & -0.519348 & 0.6070 \\
\hline $\mathrm{D}(\mathrm{LA}(-1))$ & -0.017543 & 0.131082 & -0.133831 & 0.8943 \\
\hline $\mathrm{ER}(-1)$ & -0.466834 & 0.167407 & -2.788616 & 0.0087 \\
\hline R-squared & 0.432097 & \multicolumn{2}{|c|}{ Mean dependent var } & 0.030554 \\
\hline Adjusted R-squared & 0.294424 & \multicolumn{2}{|c|}{ S.D. dependent var } & 0.120470 \\
\hline S.E. of regression & 0.101193 & \multicolumn{2}{|c|}{ Akaike info criterion } & -1.556159 \\
\hline Sum squared resid & 0.337923 & \multicolumn{2}{|c|}{ Schwarz criterion } & -1.183801 \\
\hline Log likelihood & 41.67934 & \multicolumn{2}{|c|}{ F-statistic } & 3.138568 \\
\hline Durbin-Watson stat & 1.995807 & \multicolumn{2}{|c|}{ Prob(F-statistic) } & 0.009431 \\
\hline
\end{tabular}

The table above shows that the only significant contemporaneous relation in the model is between the per capita GDP and the capital per worker. The agricultural sector does not respond contemporaneously with the economic growth (changes in the per capita GDP). However, there is a significant long relation between the economic growth and the linear summation of the capital per worker, agricultural labor per acre and the crop yields per acre. Small deviations from the equilibrium level are adjusted fast towards the equilibrium as 0.466 per cent of the deviations can be corrected annually. But large deviations, which could occur due to climatic shocks to the agriculture, would take several years to be corrected. For example, 10 per cent deviation will take 21 years to adjust completely to the pre-shock level. The long run coefficients in this co-integrating relation are estimated using the vector error correction method.

\subsection{Co-integration and vector error correction estimates}

One lag is introduced in this model with the restrictions that the per capita GDP is an endogenous variable that could not feed back to the co-integrating relation, and having the long run co-integrating vectors normalized by the long run coefficient of the log per capita GDP, the following results in table 4 are obtained (the details of the 
estimates are in annex A). The restrictions have identified all the co-integrating vectors and the likelihood ratio test shows that these restrictions are valid and cannot be rejected at $10 \%$ significance level. Furthermore, the long run coefficients have the right expected economic signs. This can be seen by presenting the relation in the equation form below:

$$
\begin{aligned}
& L Y_{t}=-8.12+0.37 L K_{t}+0.3 L A L_{t}+1.7 L A_{t} \\
& t-\text { ratios } \quad(3.5968)
\end{aligned}
$$

The capital per worker and the crop yields per acre are found to be significant and relevant factors for boosting economic growth. The presence of the crop yields per acre, other things constant, results in increasing returns to scale in the economy; whereas the capital and the labor together, other things constant, will result in decreasing returns in the economy. This proves the profound importance of the agricultural productivity in the economy. As argued throughout this paper, it is not more labor on the land but how much from land, which makes significant difference to the economic growth. The agricultural labor inputs are found irrelevant in the long run. Increased labor on land can set back the economic growth if yields are not correspondingly increased, because increased labor per land will make the law of diminishing returns quickly set in. The Granger causality tests in annex B confirm these conclusions. In these tests there is a bi-directional relation between the per capita GDP and the crop yields per acre, and a uni-directional relation from the yields per acre to the capital per worker. This means that the yields per acre do not only boost the economic growth directly but also indirectly by enhancing capital formation in the economy as high yields often enable the $70 \%$ of the population to save and buy assets.

\begin{tabular}{lc}
\hline Table 4: Vector Error Correction Estimates \\
\\
\hline Chi-square(1) & 1.397011 \\
Probability & 0.237225 \\
\hline LY(-1) & 1.000000 \\
& \\
LK(-1) & -0.369560 \\
& $(0.10275)$ \\
& {$[-3.59687]$} \\
& -0.301688 \\
LAL(-1) & $(0.28386)$ \\
& {$[-1.06282]$} \\
& -1.695782 \\
LA(-1) & $(0.46604)$ \\
& {$[-3.63868]$} \\
& 8.119524 \\
\hline
\end{tabular}

\subsection{Conclusions and policy recommendations}

Agriculture is a major engine for the economic well-being of the Gambia. The successive governments from the colonial period to the present have all recognized this importance of the agricultural sector. But most of their policies could bear any fruit, because they were working against natural laws. They in many instances encouraged slash and burn technology and putting increasingly more people onto the land instead of increasing the yields per acre. More people do remain still on the land, but they are now poorer than their forefathers. Their forefathers had one person to an acre producing on average $1100 \mathrm{~kg}$ per acre. Today, there are two persons to an acre producing the same $1100 \mathrm{~kg}$ per acre. Using four econometric techniques to examine the growth-agriculture relation in the Gambia for the period from 1966 to 2009, it is found that the capital per worker is a significant and relevant factor input for the economic growth. The agricultural labor per acre is found to be irrelevant in both the short run and the long run. The agricultural productivity measured as crop yields per acre is the most important variable for the economic growth in the Gambia. It boosts both economic growth and the capital formation in the country. The authorities should refocus their agricultural policies from putting more people back to the land to increasing the crop yields per acre. Modern technologies suitable for small and fragile lands should be adopted. The fertilizers should be substantially subsidized to increase the yields, and labor inputs onto the lands should be reduced. The 
processing, services and small manufacturing sectors should be developed and built into the agricultural policies in order to create redeployments for the agricultural labor surpluses.

\subsection{Acknowledgement}

The author acknowledges the comments and suggestions by Professor Abdoulaye Saine, Miami University, U.S.A, and Dr. Ebrima Ceesay. The endnotes and the language editing were done by them.

\subsection{Notes}

${ }^{1}$ Chr. Hennig, Rainer; "An Introduction to the Economic History of Rural Gambia", afrol News editor, http://www.afrol.com/archive/economic_history_gambia.htm

${ }^{2}$ Sessional Paper No. 133 of 1963, Report on the Census of Population of the Gambia Taken on 17th $/ 18$ April, 1963, the Government Printer, Bathurst (now Banjul), 1965

${ }^{3}$ Kuye,Rex et. Al , 2006, " the Agricultural Health in the Gambia: Agricultural Practices and Development", Review Articles, Ann Agric Environ, vol.13, p1-12

${ }^{4}$ The census of the Population of the Gambia 1963

${ }^{5}$ Colonial report, The Gambia 1962/1963

${ }^{6}$ Carney, Judith; 1998, "Women's land rights in Gambia Irrigated Rice schemes: Constraints and Opportunities", Agriculture and Human Values, vol. 15, pp. 325 336, Kluwer academic Publishers 1998.

7 http://www.statehouse.gm/agriculture/achievements.html

${ }^{8} \mathrm{http}: / /$ observer.gm/africa/gambia/kerewan/article/2008/5/7/jammeh-warns-authorities-as-rice-tops-kerewanmeeting

${ }^{9}$ Republic of the Gambia: Appraisal Report, Farmer Managed Rice Irrigation Project, African Development Fund, Agricultural and rural Development department, central and West, April 2005.

${ }^{10}$ Foroyaa News Paper, Serrekunda, the Gambia, May 8, 2009.

\section{References}

Annabi, Nabil; Cisse, Fatou,; Cockburn, John, and Decaluwe, Bernard, 2005, "trade liberalization, growth and poverty in Senegal: a dynamic micosimulation CGE model analysis", CEPII, Working paper 2005-07

Bednarikova, Z. and Doucha, T., 2009, "the Impacts of agricultural policy scenarios on development of remote rural areas - the case study of the Bruntal and Ostrava districts", Agricultural Economics - Czech 55, No. 4, 161 168

Bivand, Roger and Brunstad, Rolf, 2005, "Regional growth in Western Europe: detecting spatial misspecification using R environment", Workshop on Spatial Econometrics, Kiel Institute of World Economics, Kiel, German.

Carney, Judith A.; 1998, "Women's land rights and opportunities", Agriculture and Human Values Vol. 15, 325 - 336, Kluwer Academic Publishers

Chavas, Jean-Paul, Petrie, Ragan \& Roth, Michael, 2005, "Farm Household Production Efficiency: Evidence from the Gambia", American Agricultural Journal 87(1), 160 - 179

Clarke, R.H, 1987, "A study of agricultural credit operations of the cooperative movement in the Gambia", International Labour Organization Cooperative Development Project, Geneva Food and Agriculture Organization, 1993, FAO: "the Rice Industry in the Gambia", Rome

Dorosh, Paul A.; \& Sahn David E., 1993, "Cornell Food and Nutrition Policy Programme," Washington D.C. Working paper 39

Harley, C. Knick, 2002, "Computable general equilibrium models in economic history and an analysis of British capitalist agriculture", European Review of Economic History 6, 165 - 191

Harvey, Charles, 1990, "Improvements in Farmer welfare in the Gambia: Groundnut price subsidies and alternatives", Institute of Development Studies. Republic of the Gambia: Export Crop Subsector programme, presented at the Conference of Donors on Agriculture, Banjul, October 21 - 22, 1987.

Jabara, Cathy L., 1990, "Economic Reform and Poverty in the Gambia: A survey of Pre- and Post-ERP Experience", Cornell Food and Nutrition Policy Programme, Monograph 8,1989a, "Time and Money in the Western Sahel: Cultural Economy of interest and usury in Informal Gambian Rural Finance", Harvard Institute for International development, Cambridge MA, Development discussion paper 303

Kidane, Weldeghaber; Maetz, Materne, and Dardel, Philippe, 2006, "Food Security and agricultural development in Sub-Saharan Africa: building a case for more public support" food and Agricultural Organmization of Unietd Nations, Rome.

Kuye, Rex et al.; 2006, "Agricultural Health in the Gambia I: Agricultural Practices and Development", Review Articles, Ann Agric Environ, Vol. 13, 1- 12.

Lahiri, Sajal, 1991, "Agricultural development and the incidence of labour intensive farming", Journal of International development 3(3), $229-235$ 
Langan, Glenn E., 1987, "An assessment of agricultural inputs marketing in the Gambia within the context of the Economic Recovery Programme, report prepared for USAID, Banjul.

Liu, Xiaohe; Fang, Lan, and You, Hongye, 2007, "Agricultural trade liberalization and poverty in China: Linked CGE modelanalysis", Conference paper, Beijing, China, July 7 - 9.

Liu, Xiaohe; Buetre, Benjamin; Jian, Xu; Liu, ping, and Podbury, troy, 2005, "Developing an Input-Output table of China for detailed agricultural policy analysis", $8^{\text {th }}$ annual conference on Global Economic Analysis, Luebeck, germany, June 9 - 11 .

Lopez, Rigoberto A., and Hathie Ibrahima, 2000, "the structure of Government intervention in African Agriculture", the Journal of development Studies, Vol. 37, No.1, 57 - 72

McPherson, Malcolm F., 1991, "Structural adjustment and agriculture in the Sub-Saharan Africa: lessons from the Gambia", Harvard Institute for International development, Harvard University, Cambridge, Development Discussion paper no. 410

0' Ryani, Rand and Miller, Sebastian, 2003, "the role of agriculture in poverty alleviation, income distribution and economic development: a CGE analysis for Chile", Agricultural and development Economics division, food and Agriculture Organization of United nations, the role Roles of Agriculture International conference, Rome, Italy, October $20-22$

Ramamurthy, G. V., 1986, "Agricultural credit policy and structure: the Gambia", Report prepared for the Food and Agricultural Organization, FAO, technical Cooperation Programme, Rome.

Republic of the Gambia: Appraisal Report, "Farmer Managed Rice Irrigated Project", African Development Fund, Agricultural and Rural development, Central and West, April 2005.

Robinson, Sherman; san, Nu Nu, and Suryana, achmad, 1997, "Rice price policies in Indonesia: a computable general equilibrium analysis", Trade and Macroeconomic division, industrial Food Policy research Institute, $2033 \mathrm{~K}$ street, N.W, Washington, D.C.

Roemer, Michael, 1993, "Strategies for industrialization: lessons for the Gambia", Agency for International Development POL/CDIE/D1, Report Processing Form

Rubin, Ofir D.; Carriquiry, Miguel and Hayes, Dermot J., 2008, "Implied objectices of U.S Bio-fuel subsidies", Center for Agricultural and Rural development, Iowa State University, working paper 08 - WP 459

The Gambia: selected issues and statistical appendix, IMF country report no. 08/325, Interntional Monetary Fund, Washington D.C. October 2008

The Gambia: Selected issues and statistical appendix, IMF country report no. 07/126, International Monetary Fund, Washington D. C. March 2007, Republic of the Gambia: Credit subsector programme, presented at the Conference of Donors on Agriculture, Banjul, October 21 - 22, 1987

The Gambia: poverty Reduction Strategy Paper", IMF country report N0. 07/308, International Monetary Fund, Washington, September 2007 Republic of the Gambia: Agricultural inputs subsector programme, presented at the Conference of Donors, Banjul, October 21 - 22, 1987

Trefflich, A.; Uetrecht, I.; Efken, J.; Shaefer, M.; Steinbauer, C., and Wendt, H., 2007, "Support scheme of food processing firms: a driving force for rural development?", IAMO Forum on 'sustainable rural development: what is the role of agric-food sector?', June $27-29$, Saale, Germany.

Tokarick, Stephen, 2005, "who bears the cost of agricultural support in OECD countries?", the World Economy, vol. 28, No. 4

Von Braum, Joachim \& Puetz, Detlev, 1987, "An African fertilizer crisis: origin and economic effects in the Gambia", Cornell Food and Nutrition Policy Programme, November 1987.

Von Braum, Joachim; Puetz, Detlev \& Webb, Patrick, 1989, "Irrigation technology and commercialization of rice in the Gambia: effects on income and nutrition", International Food Research Institute, Research report 75

Von Puetz, detlev, 1992, "Agricultural Supply Response in the Gambia: a Sectoral, Household and Intra household Analysis", Wissenschaftsverlag Vank Kiel KG

Webb, Patrick, 1991, "When projects collapse: irrigation failure in the Gambia from a household perspective", Journal of International development 3(4), 339 - 353

$\mathrm{Xu}$, Dianging, 1993, "Price distortion in the transition process: a CGE analysis of China's case", Economics of Planning 26, $161-182$

Zanoli, Rafael and Danilo, Gambelli, 1999, "Output and public expenditure implications of the development of organic farming in Europe", organic farming in Europe: Economics and Policy,

Annex A: Vector Error Correction Estimates

Included observations: 42 after adjustments

Standard errors in ( ) \& t-statistics in []

Cointegration Restrictions: $B(1,1)=1, A(1,1)=0$

LR test for binding restrictions ( $\mathrm{rank}=1$ ):

Chi-square(1) 1.397011 


\begin{tabular}{|c|c|c|c|c|}
\hline Probability & 0.237225 & & & \\
\hline Cointegrating Eq: & CointEq1 & & & \\
\hline $\mathrm{LY}(-1)$ & 1.000000 & & & \\
\hline $\operatorname{LK}(-1)$ & $\begin{array}{r}-0.369560 \\
(0.10275) \\
{[-3.59687]}\end{array}$ & & & \\
\hline $\operatorname{LAL}(-1)$ & $\begin{array}{r}-0.301688 \\
(0.28386) \\
{[-1.06282]}\end{array}$ & & & \\
\hline $\mathrm{LA}(-1)$ & $\begin{array}{r}-1.695782 \\
(0.46604) \\
{[-3.63868]}\end{array}$ & & & \\
\hline $\mathrm{C}$ & 8.119524 & & & \\
\hline Error Correction: & $\mathrm{D}(\mathrm{LY})$ & $\mathrm{D}(\mathrm{LK})$ & D(LAL) & $\mathrm{D}(\mathrm{LA})$ \\
\hline CointEq1 & $\begin{array}{l}0.000000 \\
(0.00000) \\
{[\mathrm{NA}]}\end{array}$ & $\begin{array}{c}0.425194 \\
(0.13817) \\
{[3.07729]}\end{array}$ & $\begin{array}{r}-0.039842 \\
(0.06582) \\
{[-0.60534]}\end{array}$ & $\begin{array}{r}0.225492 \\
(0.09645) \\
{[2.33795]}\end{array}$ \\
\hline $\mathrm{D}(\mathrm{LY}(-1))$ & $\begin{array}{r}-0.160339 \\
(0.21137) \\
{[-0.75857]}\end{array}$ & $\begin{array}{r}-0.289298 \\
(0.33828) \\
{[-0.85521]}\end{array}$ & $\begin{array}{c}0.169003 \\
(0.14119) \\
{[1.19698]}\end{array}$ & $\begin{array}{r}-0.002636 \\
(0.20686) \\
{[-0.01274]}\end{array}$ \\
\hline $\mathrm{D}(\mathrm{LK}(-1))$ & $\begin{array}{r}0.154653 \\
(0.10287) \\
{[1.50337]}\end{array}$ & $\begin{array}{c}0.199254 \\
(0.16464) \\
{[1.21026]}\end{array}$ & $\begin{array}{r}-0.004553 \\
(0.06872) \\
{[-0.06626]}\end{array}$ & $\begin{array}{r}-0.036074 \\
(0.10068) \\
{[-0.35831]}\end{array}$ \\
\hline $\mathrm{D}(\operatorname{LAL}(-1))$ & $\begin{array}{c}0.034949 \\
(0.24748) \\
{[0.14122]}\end{array}$ & $\begin{array}{r}-0.384372 \\
(0.39607) \\
{[-0.97047]}\end{array}$ & $\begin{array}{c}0.111879 \\
(0.16531) \\
{[0.67678]}\end{array}$ & $\begin{array}{r}-0.030919 \\
(0.24220) \\
{[-0.12766]}\end{array}$ \\
\hline $\mathrm{D}(\mathrm{LA}(-1))$ & $\begin{array}{c}0.022322 \\
(0.17928) \\
{[0.12451]}\end{array}$ & $\begin{array}{c}0.347941 \\
(0.28692) \\
{[1.21269]}\end{array}$ & $\begin{array}{r}-0.028681 \\
(0.11975) \\
{[-0.23950]}\end{array}$ & $\begin{array}{c}0.019401 \\
(0.17546) \\
{[0.11057]}\end{array}$ \\
\hline $\mathrm{C}$ & $\begin{array}{r}0.025988 \\
(0.02072) \\
{[1.25433]}\end{array}$ & $\begin{array}{r}0.060957 \\
(0.03316) \\
{[1.83838]}\end{array}$ & $\begin{array}{c}0.010920 \\
(0.01384) \\
{[0.78904]}\end{array}$ & $\begin{array}{r}0.003942 \\
(0.02028) \\
{[0.19441]}\end{array}$ \\
\hline R-squared & 0.094011 & 0.314329 & 0.058175 & 0.188813 \\
\hline Adj. R-squared & -0.031821 & 0.219097 & -0.072635 & 0.076148 \\
\hline Sum sq. resids & 0.539096 & 1.380797 & 0.240544 & 0.516354 \\
\hline S.E. equation & 0.122372 & 0.195845 & 0.081742 & 0.119763 \\
\hline F-statistic & 0.747116 & 3.300661 & 0.444729 & 1.675885 \\
\hline Akaike AIC & -1.231939 & -0.291418 & -2.038932 & -1.275040 \\
\hline Schwarz SC & -0.983701 & -0.043179 & -1.790694 & -1.026802 \\
\hline Mean dependent & 0.030554 & 0.055572 & 0.018623 & 0.001043 \\
\hline S.D. dependent & 0.120470 & 0.221623 & 0.078926 & 0.124601 \\
\hline
\end{tabular}


Determinant resid covariance (dof adj.)

Determinant resid covariance

Log likelihood

Akaike information criterion

Schwarz criterion
3.92E-08

2.12E-08

132.3483

$-4.968967$

$-3.810520$

Annex B: Granger causality tests (Lags: 4)

\begin{tabular}{lccc} 
Null Hypothesis: & Obs & F-Statistic & Probability \\
LK does not Granger Cause LY & 40 & 2.11750 & 0.10235 \\
LY does not Granger Cause LK & & 0.98764 & 0.42876 \\
LAL does not Granger Cause LY & 40 & 0.48141 & 0.74914 \\
LY does not Granger Cause LAL & & 0.77203 & 0.55173 \\
& 40 & 2.67605 & 0.05017 \\
LA does not Granger Cause LY & & 2.36908 & 0.07413 \\
LY does not Granger Cause LA & 40 & 1.76992 & 0.16010 \\
& & 0.66905 & 0.61837 \\
LAL does not Granger Cause LK & & & \\
LK does not Granger Cause LAL & 40 & 2.21461 & 0.09034 \\
& & 0.75811 & 0.56046 \\
LA does not Granger Cause LK & & & \\
LK does not Granger Cause LA & 40 & 0.25834 & 0.90233 \\
& & 0.05992 & 0.99301 \\
\hline $\begin{array}{l}\text { LA does not Granger Cause LAL } \\
\text { LAL does not Granger Cause LA }\end{array}$ & & & \\
\hline
\end{tabular}

